\title{
Contribution to the smut fungi (Ustilaginomycetes) of Togo and Benin
}

\section{Teodor T. Denchev ${ }^{1}$, Harrie J.M. Sipman ${ }^{2}$ \& Cvetomir M. Denchev $^{1 *}$}

\author{
${ }^{1}$ Institute of Biodiversity and Ecosystem Research, Bulgarian Academy of Sciences, 2 Gagarin St., 1113 \\ Sofia, Bulgaria \\ ${ }^{2}$ Botanic Garden \& Botanical Museum Berlin-Dahlem, Free University of Berlin, 6-8 Königin-Luise-St., \\ D-14195 Berlin, Germany
}

Received 21 December 2014 / Accepted 26 December 2014 / Published 31 December 2014

Denchev, T.T., Sipman, H.J.M. \& Denchev, C.M. 2014. Contribution to the smut fungi (Ustilaginomycetes) of Togo and Benin. - Mycobiota 4: 25-32. doi: 10.12664/mycobiota.2014.04.02

\begin{abstract}
Sporisorium nyassae is reported for the first time from Togo and Benin. Hyparrhenia nyassae and $H$. diplandra var. mutica are recorded as new host plants of Sporisorium nyassae. Based on the current revision, Sporisorium barcinonense is removed from the list of smut fungi in Togo. Cintractia limitata is reported for the first time from Benin. All species of smut fungi known from Togo and Benin and their host plants are listed.
\end{abstract}

Key words: Benin, Cintractia, Cyperus, Hyparrhenia, smut fungi, Sporisorium, taxonomy, Togo

\section{Introduction}

The diversity of the smut fungi (Ustilaginomycotina and Microbotryales) in Western Africa is poorly known. In this region, Togo and Benin are among the least studied countries with only 19 species of smut fungi reported in the literature from Togo, and 6 species from Benin (Hennings 1907b; Scholz 1981; Mordue 1995; Piepenbring 2000; Marley et al. 2002; Vánky et al. 2011; Piątek et al. 2014).

In this article, Sporisorium nyassae from Togo and Benin, and Cintractia limitata from Benin are reported for the first time. The collections on which these records are based were discovered during a visit to the herbarium at the Botanic Garden and Botanical Museum Berlin-Dahlem (B).

\footnotetext{
*Corresponding author: e-mail: cmdenchev@yahoo.co.uk
} 


\section{Material and methods}

Dried specimens from the herbarium of the Botanic Garden and Botanical Museum BerlinDahlem were examined under light microscope (LM) and scanning electron microscope (SEM). For LM observations and measurements, spores were mounted in lactoglycerol solution ( $\mathrm{w}: \mathrm{la}: \mathrm{gl}=1: 1: 2$ ) on glass slides, gently heated to boiling point to rehydrate the spores, and then cooled. The measurements of spores are given in the form: $\min -\max$ (mean \pm 1 standard deviation). For SEM, spores were attached to specimen holders by double-sided adhesive tape and coated with gold with an ion sputter. The surface structure of spores was observed and photographed at $10 \mathrm{kV}$ accelerating voltage using a JEOL SM6390 scanning electron microscope. The description given below is based entirely on the specimens examined.

\section{Taxonomy}

Cintractia limitata G.P. Clinton, Proceedings of the Boston Society of Natural History 31: 399, 1904.

Figs 1-4

Sori surrounding the base of spikelet pedicels or peduncles, fusiform to ovoid, up to $10 \mathrm{~mm}$ long, initially covered by a brownish peridium which later flakes away; in old sori, the plant axis may be split. Spore mass semi-agglutinated, powdery on the surface, very dark reddish brown, formed in pockets of fungal stroma. Spores flattened, in plane view orbicular, suborbicular or broadly elliptic in outline, sometimes slightly irregular, in plane view (9.5-)10-13(-14) × (9-)9.5-12(-12.5) (11.7 $\pm 0.8 \times 10.7 \pm 0.7) \mu \mathrm{m}(\mathrm{n}=50)$, in side view 7-8.5 $\mu \mathrm{m}$ thick, middle reddish brown; wall more or less evenly thickened, $0.7-0.9$ $\mu \mathrm{m}$ thick, in LM smooth to punctate, spore profile not affected; in SEM densely punctate, warts up to $0.1 \mu \mathrm{m}$ high.

Specimen examined - On Cyperus cf. rotundus L.: BENIN, ATLANTIQUE DEPARTMENT, Ouidah, 6 Oct 1974, leg. A. Mathey \& H. Scholz, no. 770 (B, sine num.).

Cyperus rotundus is distributed in tropical and subtropical regions. Cintractia limitata is widely distributed in the tropics and subtropics, mainly on plants of the genus Cyperus, as well as on some species of Kyllinga and Pycreus. In Africa, this smut fungus has been previously reported from Cameroon, Congo, Ethiopia, Gabon, Ghana, Guinea, Ivory Coast, Malawi, Nigeria, Reunion, Sierra Leone, South Africa, Sudan, Tanzania, Togo, Uganda, Zambia, and Zimbabwe (Hennings 1907a, b; Ling 1950; Piepenbring 2000; Vánky 2011; Vánky et al. 2011; Denchev \& Denchev 2012; etc.).

Sporisorium nyassae (Syd. \& P. Syd.) Vánky \& Minnis, Smut fungi of the world: 1339, 2011[2012]. - S. transfissum (Tul. \& C. Tul.) G. Deml, Zeitschrift für Mykologie 49: 174, 1983.

Figs 5-8

Sori in all of the spikelets of the raceme, all racemes of an inflorescence affected, 2-3.5 $\times 0.5-0.7 \mathrm{~mm}$, initially ovoid, completely concealed by the glumes and inconspicuous, later the glumes are spreading slightly, fusiform; initially covered by a thin yellowish brown peridium that soon flakes away in the upper part of the sorus, exposing a single, filiform, not branching columella with longitudal furrows, surrounded by semi agglutinated to 

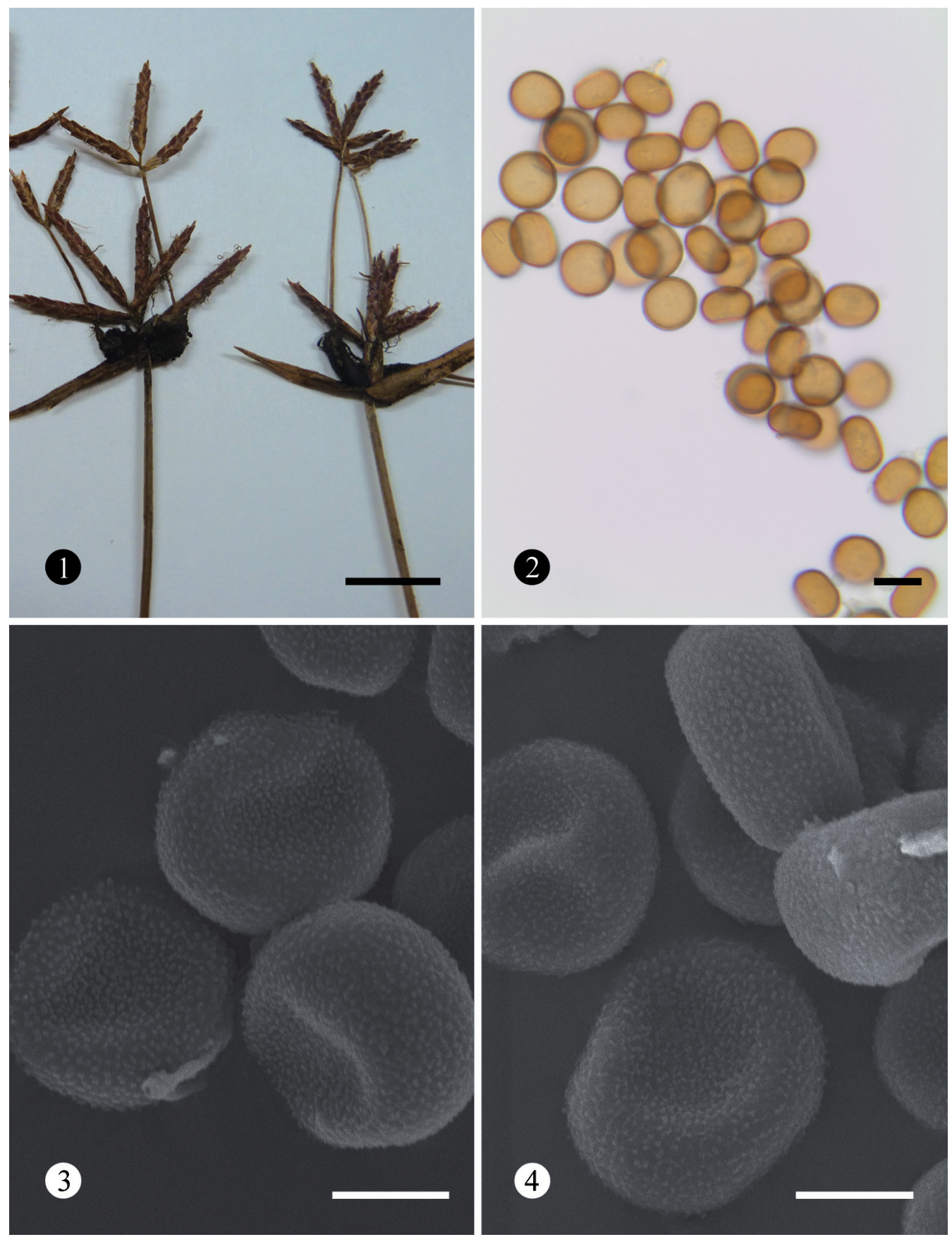

Figs 1-4. Cintractia limitata on Cyperus cf. rotundus from Benin (A. Mathey \& H. Scholz, no. 770). 1. Sori. 2. Spores in LM. 3-4. Spores in SEM. Scale bars: $1=1 \mathrm{~cm}, 2=10 \mu \mathrm{m}$, $3-4=5 \mu \mathrm{m}$ 
powdery blackish brown mass of spores and sterile cells. Sterile cells in small irregular groups, variable in shape, often collapsed, $8.5-17.5 \mu \mathrm{m}$ long, hyaline or subhyaline, wall 0.6-1.1 $\mu \mathrm{m}$ thick, smooth. Spores globose, subglobose, broadly ellipsoidal, ovoid or slightly irregular, $(10-) 11-15(-16.5) \times(9-) 10-13(-14)(12.6 \pm 0.9 \times 11.1 \pm 0.7) \mu \mathrm{m}\left(\mathrm{n}_{4}=200\right)$, not dimorphic, middle reddish brown, with one or two paler, rounded areas (germ pores) of 2.5-4 $\mu \mathrm{m}$ diameter; wall evenly or almost evenly thickened, $0.6-0.9 \mu \mathrm{m}$ thick, in LM punctate, spore profile not affected; in SEM minutely echinulate, spinules up to $0.3 \mu \mathrm{m}$ high, between the spinules densely punctate.

Specimens examined - On Hyparrhenia nyassae (Rendle) Stapf: TOGO, KARA REGION, Réserve de Chasse de la Kéran, Souté, 31 Jul 1979, leg. U. Scholz, P. Koumassi, H. Kühn \& H. Peuker, no. 290A, det. H. Scholz (as Sphacelotheca barcinonensis, B, sine num.). - On Hyparrhenia diplandra var. mutica (Clayton) Cope (H. mutica Clayton): TOGO, CENTRALE REGION, N of Sokodé, 21 Sep 1976, leg. H. Ern, B. Hein \& A. Pircher, no. 812A, det. H. Scholz (as Sphacelotheca barcinonensis on Hyparrhenia diplandra, B, sine num.); TOGO, CENTRALE REGION, Park national de Fazao, near Fazao, 400500 m, 8 Aug 1979, leg. U. Scholz, P. Koumassi, H. Kühn \& H. Peuker, no. 445A, det. H. Scholz (as Sphacelotheca barcinonensis on Hyparrhenia diplandra, B, sine num.); BENIN, ATAKORA DEPARTMENT, $20 \mathrm{~km}$ from Natitingou, toward Boukoumbé, 11 Oct 1999, leg. J. Krohmer, no. K 6776 (B 70 0015515).

Two of the cited Togolese specimens (U. Scholz et al., no. 290A, and U. Scholz et al., no. 445A) are mistakenly identified by Scholz (1981: 104) as Sphacelotheca barcinonensis (a species currently transferred in Sporisorium). Sporisorium barcinonense (Riofrio) Vánky differs from Spor. nyassae in having larger spores, 13-18(-20) $\mu \mathrm{m}$ long. This species was known to infect Hyparrhenia hirta in South Europe (Italy and Spain) and Africa (Canary Islands and Togo) (Scholz 1981; Vánky 2003; Vánky et al. 2011). Based on the current revision, Sporisorium barcinonense should be removed from the list of smut fungi in Togo.

Hyparrhenia nyassae is reported here for the first time as a host plant of Sporisorium nyassae. It is distributed in Tropical and Southern Africa, Madagascar, and Indo-China.

The host plants of two of the cited Togolese specimens were identified by H. Scholz as Hyparrhenia diplandra. In fact, these specimens do not belong to the typical variety of this species but to var. mutica. The presence of an awnless superior lemma of the sessile spikelet is a feature that taxonomically distinguishes $H$. diplandra var. mutica from the typical variety. Hyparrhenia diplandra var. mutica is a new host record for Sporisorium nyassae. This plant has a scattered distribution in tropical Africa - from Sierra Leone and Liberia through Western and Central Africa to Ethiopia, south to Mozambique and Zambia (Cope 2002; Friis et al. 2011).

Sporisorium nyassae has been previously reported from Africa (Algeria, Chad, Congo, Madagascar, Malawi, Morocco, South Africa, and Zimbabwe) on Hyparrhenia anamesa Clayton, $H$. diplandra (Hack.) Stapf, H. hirta (L.) Stapf (incl. H. hirta var. longiaristata Rothm. \& P. Silva), H. newtonii var. macra Stapf, H. quarrei Robyns, H. rufa (Nees) Stapf, H. tamba (Steud.) Stapf, and Hyperthelia dissoluta (Nees ex Steud.) Clayton, and from South Europe (Portugal and Spain) on Hyparrhenia hirta (Zambettakis 1970, 1979; Vánky 2003, 2011; Vánky et al. 2011). This smut fungus is recorded here for the first time from Togo and Benin. 

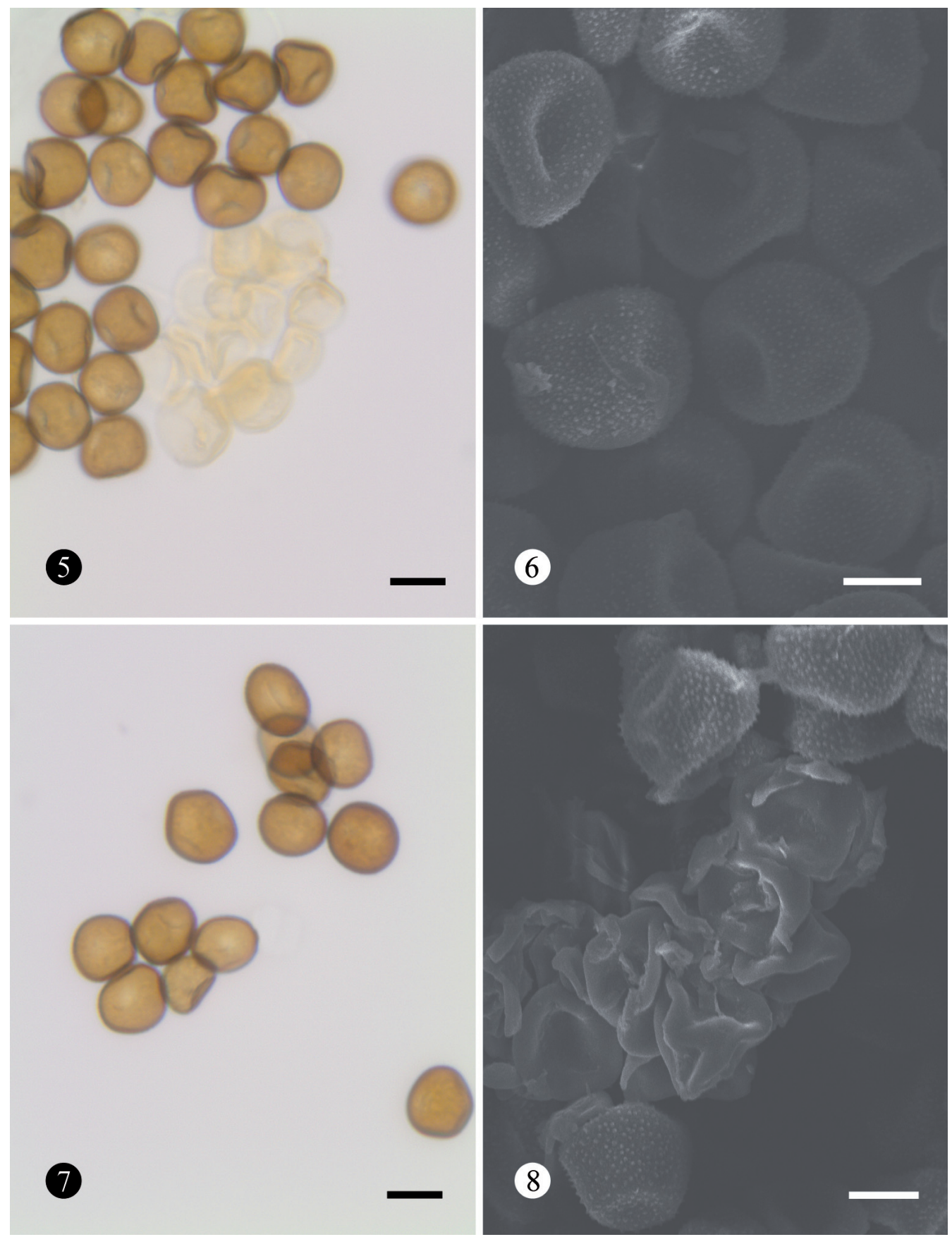

Figs 5-6. Sporisorium nyassae on Hyparrhenia nyassae from Togo (U. Scholz et al., no. 290A). 5. Spores and sterile cells in LM. 6. Spores in SEM. Figs 7-8. Sporisorium nyassae on Hyparrhenia diplandra var. mutica from Benin (B 70 0015515). 7. Spores in LM. 8. Spores and sterile cells in SEM. Scale bars: 5, $7=10 \mu \mathrm{m}, 6,8=5 \mu \mathrm{m}$ 


\section{Checklists of the smut fungi in Togo and Benin}

The following 20 species are currently known from Togo (Hennings 1907b; Scholz 1981; Mordue 1995; Piepenbring 2000; Marley et al. 2002; Vánky et al. 2011; present article):

Anthracocystis ehrenbergii (J.G. Kühn) McTaggart \& R.G. Shivas on Sorghum bicolor (L.) Moench

Anthracocystis ischaemoides (Henn.) McTaggart \& R.G. Shivas (syn. Sporisorium ischaemoides (Henn.) Vánky) on Schizachyrium sanguineum (Retz.) Alston

Cintractia axicola (Berk.) Cornu on Fimbristylis dichotoma (L.) Vahl var. dichotoma (TOGO, KARA REGION, W of Kragouda, near Kuwde, NW of Farendé, 10 May 1978, leg. M. Hakki et al., no. 912, det. T.T. Denchev \& C.M. Denchev, B 10 0506828) and F. pilosa Vahl (Scholz 1981, as Cintractia limitata)

Cintractia limitata G.P. Clinton (syn. C. togoensis Henn.) on Cyperus cyperoides (L.) Kuntze (C. macrocarpus var. pseudoflavus (C.B. Clarke) Kük., Mariscus cylindristachyus Steud.) and $C$. tenuiculmis Boeckeler

Conidiosporomyces ayresii (Berk.) Vánky \& R. Bauer on Panicum maximum Jacq., Setaria helvola (L.f.) Roem. \& Schult. (syn. Setaria pallide-fusca (Schumach.) Stapf \& C.E. Hubb.), and S. sphacelata (Schumach.) Stapf \& C.E. Hubb. ex Moss Moesziomyces bullatus (J. Schröt.) Vánky on Pennisetum glaucum (L.) R. Br. Sporisorium andropogonis (Opiz) Vánky on Andropogon pteropholis Clayton Sporisorium andropogonis-tectorum (L. Ling) Vánky on Andropogon tectorum Schumach. \& Thonn.

Sporisorium chudeaui (Har. \& Pat.) Vánky on Vetiveria nigritana (Benth.) Stapf

Sporisorium cruentum (J.G. Kühn) Vánky on Sorghum bicolor (L.) Moench

Sporisorium moniliferum (Ellis \& Everh.) L. Guo (Ustilago warneckeana Henn.) on Heteropogon contortus (L.) P. Beauv. ex Roem. \& Schult.

Sporisorium nyassae (Syd. \& P. Syd.) Vánky \& Minnis on Hyparrhenia nyassae and $H$. diplandra var. mutica (in the present article)

Sporisorium reilianum (J.G. Kühn) Langdon \& Full. on Sorghum arundinaceum (Desv.) Stapf and S. bicolor (L.) Moench

Sporisorium sorghi Ehrenb. ex Link on Sorghum arundinaceum (Desv.) Stapf and S. bicolor (L.) Moench

Sporisorium vanderystii (Henn.) Langdon \& Full. on Hyparrhenia sp.

Tilletia barclayana (Bref.) Sacc. \& P. Syd. on Oryza sativa L.

Tolyposporium kuwanoanum (Togashi \& Y. Maki) Denchev \& T. Denchev (syn. Thecaphora africana H. Scholz) on Lipocarpha kernii (Raymond) Goetgh. (Rikliella kernii (Raymond) J. Raynal)

Tranzscheliella hypodytes (Schltdl.) Vánky \& McKenzie on Andropogon gayanus Kunth Ustilago microchloae Syd., P. Syd. \& E.J. Butler on Microchloa indica (L. f.) P. Beauv. Ustilago rabenhorstiana J.G. Kühn on Digitaria cf. nuda Schumach.

To our knowledge, only six species of smut fungi have been previously recorded from Benin (Marley et al. 2002; Vánky et al. 2011; Piątek et al. 2014). Furthermore, five of these species 
are parasites on cultivated plants (sorghum and pearl millet) and only one is found on a wild plant. With the newly reported species, the number of the known smut fungi becomes eight.

Anthracocystis ehrenbergii (J.G. Kühn) McTaggart \& R.G. Shivas on Sorghum bicolor (L.) Moench

Cintractia limitata G.P. Clinton (syn. C. togoensis Henn.) on Cyperus cf. rotundus (in the present article)

Moesziomyces bullatus (J. Schröt.) Vánky on Pennisetum glaucum (L.) R. Br.

Sporisorium cruentum (J.G. Kühn) Vánky on Sorghum bicolor (L.) Moench

Sporisorium elegantis Vánky on Thelepogon elegans Roth

Sporisorium nyassae (Syd. \& P. Syd.) Vánky \& Minnis on Hyparrhenia diplandra var. mutica (in the present article)

Sporisorium reilianum (J.G. Kühn) Langdon \& Full. on Sorghum bicolor (L.) Moench Sporisorium sorghi Ehrenb. ex Link on Sorghum bicolor (L.) Moench

Acknowledgements. This research received support from the SYNTHESYS Project http:// www.synthesys.info/ which is financed by European Community Research Infrastructure Action under the FP7 "Capacities" Program.

\section{References}

Cope, T. 2002. Hyparrhenia E. Fourn. - In: G.V. Pope, \& E.J. Martins (eds). Flora Zambesiaca. Vol. 10(4). Pp. 95-134. Royal Botanic Gardens, Kew.

Denchev, C.M. \& Denchev, T.T. 2012. New records of smut fungi. 6. - Mycotaxon 121: 215-223.

Friis, I., Phillips, S.M., Gilbert, M.G., Challen, G., Schrire, B., Demissew, S. \& Bidgood, S. 2011. New additions to the Flora of Ethiopia and Eritrea in the families Euphorbiaceae, Fabaceae (Legwninosae), Lamiaceae, Campanulaceae, Eriocaulaceae and Poaceae. - Symbolae Botanicae Upsalienses 35(2): 107-128.

Hennings, P. 1907a. Fungi Africae orientalis. IV. - Botanische Jahrbücher für Systematik, Pflanzengeschichte und Pflanzengeographie 38: 102-118.

Hennings, P. 1907b. Fungi camerunenses. IV. - Botanische Jahrbücher für Systematik, Pflanzengeschichte und Pflanzengeographie 38: 119-129.

Ling, L. 1950. Studies in the genus Cintractia. II. Cintractia axicola and related species. - Mycologia 42: 646-653.

Marley, P.S., Diourté, M., Neya, A., Nutsugah, S.K., Sérémé, P., Katilé, S.O., Hess, D.E., Mbaye, D.F. \& Ngoko, Z. 2002. Sorghum and pearl millet diseases in West and Central Africa. - In: J.F. Leslie (ed.). Sorghum and millets diseases. Pp. 419-425. Iowa State Press, Ames.

Mordue, J.E.M. 1995. Cintractia peribebuyensis. IMI Descriptions of fungi and bacteria, no. 1242. Mycopathologia 131: 43-44.

Piątek, M., Piątek, J. \& Yorou, N.S. 2014. Emended description and geographical distribution of Sporisorium elegantis (Ustilaginaceae), a species shared between West Africa and India. - Phytotaxa 175: 148-154. 
Piepenbring, M. 2000. The species of Cintractia s. 1. (Ustilaginales, Basidiomycota). - Nova Hedwigia 70: 289-372.

Scholz, H. 1981. Die Gramineen- und Cyperaceen-Brandpilze (Ustilaginales) aus Togo. - Willdenowia 11: 101-113.

Vánky, K. 2003. The smut fungi (Ustilaginomycetes) of Hyparrhenia (Poaceae). - Fungal Diversity 12: 179-205.

Vánky, K. 2011['2012']. Smut fungi of the world. APS Press, St. Paul, Minnesota, USA.

Vánky, K., Vánky, C. \& Denchev, C.M. 2011. Smut fungi in Africa - a checklist. - Mycologia Balcanica 8: 1-77.

Zambettakis, C. 1970. Recherches sur les Ustilaginales d'Afrique. - Bulletin de la Société Mycologique de France 86: 305-692.

Zambettakis, C. 1979. Recherches sur les Ustilaginales. (Supplément sur les espèces africaines). - Bulletin de la Société Mycologique de France 95: 393-443. 